\title{
2. Indicators of impact or outcome
}

\subsection{Impact/outcome of libraries}

Libraries have always been able to calculate the input into their services (funding, staff, collections, space, equipment) and the output of those services (loans, visits, downloads, reference transactions, etc). Measures have also been developed for assessing the quality of library services and the cost-efficiency of the library's performance. Performance measurement evaluates whether a library is effective and efficient in delivering its services.

But quantity of use and quality of performance do not yet prove that users benefited from their interaction with a library. Measuring impact or outcome means going a step further and trying to assess the effect of services on users and on society. "Impact" and "outcome" are often used synonymously in the professional literature, but "outcome" is also used for the output/usage of library services (e.g. a user reading a book), while "impact" is also seen as the broader term, denoting changes in users (e.g. the user gaining knowledge). ${ }^{28}$

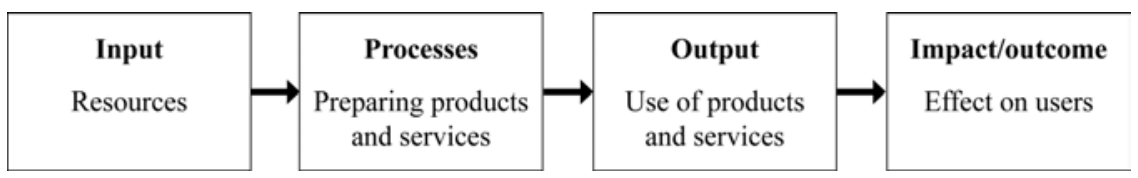

Outcome or impact means that there is a change in a user's skills, knowledge, or behaviour.

"Outcomes are the results of library use as affecting the individual user." 29

"Outcomes are the ways in which library users are changed as a result of their contact with the library's resources and programs." 30

What changes can a library effect in users? Using library services can further

\footnotetext{
${ }^{28}$ Brophy, P. (2005), The academic library, $2^{\text {nd }}$ edition, Facet, London, p. 189

${ }^{29}$ Revill, D. (1990), Performance measures for academic libraries, in Kent, E. (Ed.), Encyclopedia of Library and Information Science, Dekker, New York, Basel, Vol.45, Suppl.10, p.316

${ }^{30}$ ACRL. Association of College and Research Libraries. Task Force on Academic Library Outcomes Assessment Report. June 27 1998, available at: http://www.ala.org/ala/acrl/ acrlpubs/whitepapers/taskforceacademic.htm
} 
- knowledge,

- information literacy,

- democracy (access to information for all),

- higher academic or professional success,

- social inclusion (e.g. of elderly people or immigrants),

- lifelong learning,

- individual well-being.

Short-term effects even of a single library visit may be that users find relevant information, can solve a problem, save time in their work, gain searching skills and self-reliance in using information.

Long-term effects of using library services could be permanently higher information literacy, higher academic or professional success, changes in attitudes and motivation (e.g. motivation to read), and changes in information behaviour (e.g. using a broader variety of information resources).

The changes could be seen as a pyramid, going from cognitive impacts (knowledge acquisition) to changes in attitudes and opinions and lastly to changes in behaviour.

\subsection{Methods for assessing impact/outcome}

For several years, projects worldwide have tried to find methods for proving an outcome of library services. ${ }^{31}$ The main problem for such methods is that influences on an individual are manifold and that therefore it is difficult to trace changes and improvements in users back to the library. Nevertheless, there are quite a number of possible methods that have already yielded interesting results. They can be roughly differentiated into quantitative and qualitative methods. ${ }^{32}$

Qualitative ("soft") measures, developed in social science, try to assess outcomes by evaluating users' experiences and opinions. Methods used are:

- Surveys (print, telephone, or online)

- Interviews

- Focus groups, discussion groups

- Users' self-assessment of skills and competences gained

\footnotetext{
${ }^{31}$ An overview of ongoing research is given in: Poll, R., Bibliography "Impact and outcome of libraries", available at: http://www.ulb.uni-muenster.de/outcome

32 Poll, R. and Payne, P. (2006), Impact measures for libraries and information services, $L i$ brary High Tech 24,2, pp. 547-562, available at: http://conference.ub.uni-bielefeld.de/2006/ proceedings/payne_poll_final_web.pdf
} 
The methods have not only been used with actual library users, but also with non-users and the general public in order to gain estimates of potential outcomes of libraries.

In surveys, interviews or discussion groups, users and non-users are asked for

- direct benefit from using library services,

- potential benefits from using libraries or a specified library,

- indirect (potential) benefit of a library's existence, (e.g. free access to information, cultural life in the community, children's literacy, social inclusion),

- potential value of libraries for future users (e.g. preservation of the national documentary heritage).

Users' self-assessment of their benefits has proved less reliable, as users tend to over-estimate the competences gained.

Qualitative methods have been frequently used in public libraries in order to show their social impact and local importance. ${ }^{33}$ Such qualitative methods will deliver a rich fund of "stories" that show what users think about actual or potential benefits of libraries. This "anecdotal evidence" helps to elucidate and corroborate the results of quantitative measuring, but it should be organized and made quantifiable to be convincing. The Museums, Libraries and Archives Council, London, cites such quantified results in a conspicuous place on its website, e.g.:

" $70 \%$ of children believe that a library is one of the best places to learn, outside school." 34

It should always be kept in mind that results gained by qualitative methods will have a subjective bias. They show the "perceived benefit", but do not prove benefit. They should therefore be compared with results of quantitative methods or with statistics of library usage in order to validate the results.

Quantitative methods try to obtain tangible data for a change in user competences or behaviour or to find correlations between library use and a person's academic or professional success. The following methods have been used:

\footnotetext{
${ }^{33}$ Bohme, S. and Spiller, D. (Ed.) (1999), Perspectives of public library use 2. A compendium of survey information, Library \& Information Statistics Unit (LISU), Loughborough; Debono, B. (2002), Assessing the social impact of public libraries : what the literature is saying, Australasian Public Libraries and Information Services 15,2, pp. 80-95; Linley, R. and Usherwood, B. (1998), New measures for the new library: a social audit of public libraries, British Library Research and Innovation Centre Report 89, British Library Board, London

${ }^{34}$ MLA. Museums, Libraries and Archives Council, available at: http://www.mla.gov.uk/
} 
- Tests that assess user skills before and after a library training lesson or the use of library services

- Performance monitoring/data mining

- Unobtrusive observation of users

- Analysis of citations in course work or research publications over years

- Comparison of success data with data of library use

Tests for assessing changes in users' skills and competences are today widely applied in libraries, especially for evaluating the learning outcome of a library's information literacy training. Such tests can be used before and after a training session or a series of training sessions in order to show differences in the competence of finding and evaluating relevant information. Tests for measuring training impact will be compulsory when a library's information literacy modules are included in the curriculum of its institution. ${ }^{35}$

Performance monitoring, data mining and unobtrusive observation have been used for tracing users' searching procedures, their search terms, and their use of help functions. These methods can show successes, failures and problems. When the study is repeated regularly, results may trace quantifiable changes in the searching skills of users.

Analysis of bibliographies in users' papers, especially in doctoral dissertations, has been used for two different purposes:

1. To assess the importance of the local library for research and study: The citations in research papers are compared with the local collection (including electronic resources licensed by the library). The results show how far the materials cited in the papers have been (or could have been) accessed via the local library and thus whether the local library offers sufficient material for research. ${ }^{36}$

\footnotetext{
${ }^{35}$ For literature on the outcome of information literacy training see: Poll, R., Bibliography "Impact and outcome of libraries", Part 3, available at: http://www.ulb.uni-muenster.de/out come

${ }^{36}$ Ahtola, A. A. (2002), How to evaluate and measure the impact of the library's collection on the learning outcome? 68th IFLA Council and General Conference, available at: http://www.ifla.org/VII/s2/conf/ahtola.pdf; Kayß, M. and Poll, R. (2006), Unterstützen Bibliotheksbestände die Forschung? Zitatanalyse in Dissertationen, B.I.T. online 2006,2, available at: http://www.b-i-t-online.de/archiv/2006-02-idx.html; Smith, E. T. (2003), Assessing collection usefulness: an investigation of library ownership of the resources graduate students use, College \& Research Libraries 64, pp. 344-355
} 
2. To show whether there are changes over time or after library training sessions as to the accuracy of citations, the currency of cited titles, the type of resources used or the number of electronic resources cited. ${ }^{37}$

It would of course be most interesting to funding institutions to know whether library services positively influence the academic or professional success of users. For assessing such influence, data as to the frequency of library use and the type of services used are set in relation to data about the same persons' success. This method has especially been used for students' success, described by data like

- duration of studies,

- grades in exams,

- student persistence (retention),

- employment rates after exams.

A number of projects worldwide have tried to find a correlation between the use of library services and the success of users. ${ }^{38}$ Problems occur when data protection rules forbid the use of personal data, but even comparing groups of users has yielded valid results in some cases. ${ }^{39}$

\subsection{Assessing the financial value of libraries}

In the frame of outcome assessment, libraries have also tried to "measure" their economic value. The funding that is necessary for libraries (collections, buildings, equipment, and especially staff) constitutes a considerable factor in the budget of universities or communities, and funding institutions and the taxpayers will want to see whether investment in libraries yields "value for money".

Libraries have tried to answer this question, including the actual and the potential economic benefit as well for single users as for the general public. As most library services have no equivalent on the common market and therefore

\footnotetext{
${ }^{37}$ Emmons, M. and Martin, W. (2002), Engaging conversation: evaluating the contribution of library instruction to the quality of student research, College and Research Libraries 63, pp. 545-560; Tunón, J. and Brydges, B. (2006), Improving the quality of university libraries through citation mining and analysis using two new dissertation bibliometric assessment tools, World Library and Information Congress: 71th IFLA General Conference and Council, available at: http://www.ifla.org/IV/ifla71/papers/078e-Tunon_Brydges.pdf

38 see: Poll, R., Bibliography "Impact and outcome of libraries", Part 4, available at: http:// www.ulb.uni-muenster.de/outcome

${ }^{39}$ de Jager, K. (2002), Impacts and outcomes: searching for the most elusive indicators of academic library performance, Proceedings of the 4th Northumbria International Conference on Performance Measurement in Libraries and Information Services, Washington DC, Association of Research Libraries , pp. 291-297
} 
no "market prices" for services can be determined, two other ways have been tried for assessing the economic value of libraries:

- Assessing time costs ("replacement value of a client's time")

- Using the contingent valuation method

Measuring time costs starts from the assumption: When users invest time and effort in order to use library services the financial value that they - or their institution - place on that use must be at least as high as their "sacrifice" of time. The time costs of library usage are calculated by multiplying the time users spend on library services with the average salary costs of the population served by that library. The problems of this method are that in many cases it will not be possible to calculate average salaries, e. g. for students, and that the time costs of library usage might as well be seen as just another cost factor, not as a financial value achieved by the library.

More promising is the contingent valuation method that has been developed for assessing the financial value of non-profit organisations and services, especially for projects in health care, environmental protection, education or culture. ${ }^{40}$ Persons that would be directly or potentially interested in a specified organisation or its services are asked to rate the value of the organisation or service in financial terms, expressed by their "willingness-to-pay" or "willingness-to-accept". For assessing the financial value of libraries, the questions could be:

- Willingness-to-pay: What would you pay for maintaining this library/this particular library service?

- Willingness-to-accept: Which sum would you accept as an equivalent if this library/this particular library service were given up?

Usually, the interviewees are given options between sums they would pay (e.g. in higher taxes) or accept (e.g. in lower taxes). The problem of this method is that people are asked to financially rate services or institutions that they never thought of in terms of money. The contingent valuation method has already been frequently applied for public libraries. ${ }^{41}$ The British Library used this method

\footnotetext{
${ }^{40}$ see e. g. Mitchell, R. C. and Carson, R. T. (1993), Using surveys to value public goods, the contingent valuation method, Resources for the Future, Washington

${ }^{41}$ Aabø, S. (2005), The value of public libraries in Norway, Bibliotekforum 6, pp. 38-40; Holt, G. E., Elliott, D. and Moore, A. (1999), Placing a value on public library services, Public Libraries 38, pp. 89-108; Morris, A., Hawkins, M. and Sumsion, J. (2001), The economic analysis of public libraries, Library and Information Commission Research Report 89, British Library, London
} 
with the impressive result that for every $£ 1$ of public funding that the British Library receives each year, $£ 4.4$ are generated for the national economy. ${ }^{42}$

\subsection{Impact/outcome assessment and performance measurement}

Performance measures assess the quality of library services, either by quantitative data or by users' perception of the quality. Assessing impact or outcome tries to find out whether library services have an identifiable effect on users.

It might be assumed that services with good quality (speed, reliability, userorientation) will have more positive impact on users than services with poor performance. If outcome assessment shows that the outcomes that the library intends to achieve are not reached, performance measurement can help to identify problems or failures in the service delivery that may lead to minimally positive or even negative outcome on users.

Information literacy training is a good example for showing relations between impact and performance assessment. If attendants of training sessions do not show higher skills in tests after the training, the library could use satisfaction surveys in order to find reasons for poor impact. It could also use indicator B.10 "Attendances at training lessons per capita" to see whether the lessons attract a sufficient part of the population.

Another example is the relation between library use and academic success of users. If the results of such comparison show that students with high success have not used library services frequently, again satisfaction surveys will help to detect reasons for non-use of certain services. The library might then apply specified indicators for measuring the quality of those services in order to see whether insufficient service delivery has influenced the use of services and thus impeded possible positive outcomes on users.

\subsection{Projects of outcome assessment}

A number of projects worldwide are trying to find methods, measures, and tools for assessing impact/outcome of libraries and information services.

- The eVALUEd Project, based within the evidence base at the University of Central England, was set up to develop a transferable model for e-

\footnotetext{
${ }^{42}$ Pung, C., Clarke, A. and Patten, L. (2004), Measuring the economic impact of the British Library, New Review of Academic Librarianship 10,1, pp. 79-102
} 
library evaluation in higher education. The project produced a toolkit for evaluating electronic information services ${ }^{43}$.

- IMLS (Institute of Museum and Library Services) fosters outcome-based evaluation of projects. ${ }^{44}$

- The New Measures Initiative of ARL (Association of Research Libraries) includes several outcome-related programs ${ }^{45}$ :

- Learning Outcomes

- Higher Education Outcomes Research Review

- MINES (Measuring the Impact of Networked Electronic Services)

- IBEC, a joint research initiative of the Information School of the University of Washington and the University of Michigan School of Information has developed a toolkit for assessing the impact of information in communities. $^{46}$

- SCONUL (Society of College, National and University Libraries) and LIRG (Library and Information Research Group) have started an impact initiative. $^{47}$

${ }^{43}$ available at: http://www.evalued.uce.ac.uk/index.htm

44 available at: http://www.imls.gov/index.shtm

${ }^{45}$ available at: http://www.arl.org/stats/initiatives/index.shtml

${ }^{46}$ available at: $\mathrm{http}: / /$ ibec.ischool.washington.edu/default1024 $\operatorname{aspx}$ ? cat $=$ Home $\& \mathrm{~b}=\mathrm{y}$

47 available at: $\underline{\text { http://www.sconul.ac.uk/groups/performance improvement/impact } 2 . h t m l}$ 